\title{
Prevalence and Profile of Malnutrition in Under-Five Children with Congenital Heart Diseases in Cairo University Pediatric Hospitals
}

\author{
Nargis Albert Labib ${ }^{1}$, Hala Salah Hamza ${ }^{2}$, Amal Samir Sedrak ${ }^{1 *}$, Amira Ahmed Hegazy ${ }^{1}$ \\ ${ }^{1}$ Public Health Department, Faculty of Medicine, Cairo University, Cairo \\ ${ }^{2}$ Pediatric Department Faculty of medicine Cairo University
}

\begin{abstract}
:
Background: Malnutrition among children with Congenital Heart Disease (CHD) is considered a major public health problem causing significant impact on children morbidity and mortality. Objectives: The study aimed to assess the prevalence and epidemiological pattern of malnutrition among under-five Egyptian children with CHD. Methods: A cross sectional analytical study design included 300 children, having uncomplicated CHD. Hemoglobin level, serum iron and total iron binding capacity were recorded. Additionally, Anthropometric measurements were assessed and $\mathrm{Z}$ scores were calculated for weight for age (WAZ), weight for height (WHZ), and height for age (HAZ) have been calculated. Malnutrition was defined as weight, height, and weight/height $\mathrm{Z}$ score $<-2$. Results: Generally, prevalence of malnutrition among the studied sample of CHD children was $47 \%$. Forty-four percent of the studied population were underweight, $29.7 \%$ were stunted, while wasting was only $6.7 \%$. Malnutrition was significantly higher among those with low income compared to their expenditure $(\mathrm{P}=0.038)$ and was significantly lower in those breastfed on regular intervals compared to those fed on demand $(\mathrm{P}=0.002)$. Additionally, malnutrition was significantly higher in those receiving complementary feeding compared to those breastfed or bottle fed only ( $\mathrm{P}$ value 0.03).Conclusion: Malnutrition is an obvious complicating problem in children with CHD, associated with existence of anemia, breastfeeding on demand and early- starting of complementary feeding.
\end{abstract}

Keywords: Anemia, Congenital heart disease, Egyptian under 5 children, Malnutrition

\section{Introduction:}

Congenital heart disease (CHD) represents the majority of human developmental abnormality, with reported prevalence estimated to be 4-10 per 1000 live births. ${ }^{1}$ Infants and children with CHD constantly suffer from malnutrition, and failure to thrive, with the prevalence of significant CHD related malnourishment reaching around 40\% of CHD patients. The etiology of these problems is multi-factorial, but basically related to the fact that these children face considerable challenges of energy imbalance between the caloric intake and expenditure, especially that caloric intake standards are lacking in the case of children with CHD, making these standards inadequate to permit normal growth rates among children. ${ }^{2-5}$

Numerous studies highlighted the association between malnutrition among children with CHD and higher prevalence of morbidity and mortality. This was indicated by recurrent hospitalization, poor surgical outcomes, continual impairment of somatic growth, and increased death rates. ${ }^{6-8}$ All children with CHD should be regularly checked by a pediatric cardiologist to monitor their cardiac condition. In addition, and with

*Corresponding author: E-mail: amalnewlife82@gmail.com 
no less importance, a primary health care provider should assess their growth and nutrition, attainment of developmental milestones, ensure timely introduction of immunizations and manage common pediatric illnesses and injuries. ${ }^{9}$

In Egypt, like many other developing countries, pediatric cardiac programs are not well-established and epidemiological profile of CHD-related malnutrition is deficient. Therefore, this study aimed to assess the prevalence, the epidemiological pattern alongside with the predictors of malnutrition among under-five years of age, Egyptian children with CHD.

\section{Methods:}

Setting and design: The present crosssectional, analytical study was conducted in the pediatrics hospital - Kasr Al Ainy Medical School (Aboul Rish Pediatrics hospital), Cairo University in Egypt. The pediatric outpatient cardiology clinic manages approximately $30-$ 80 patients daily. The study was conducted in the period from May 2015 till October 2015. Sample size, population and sampling method: The sample size was calculated using open-epi online calculator, ${ }^{10}$ and applying the formula where the sample size $\mathrm{n}=[\mathrm{DEFF} * \mathrm{~Np}(1-\mathrm{p})] / \quad[(\mathrm{d} 2 / \mathrm{Z} 21-\alpha / 2 *(\mathrm{~N}-$ $\left.1)+p^{*}(1-p)\right] n=$ the desired sample size, $Z=$ standard deviation at $95 \%$ confidence level (1.96), $\mathrm{p}$ is the proportion in the target population estimated to have a particular characteristic. Since there are no previous studies regarding this topic in Egypt, $\mathrm{p}$ is considered as $50 \%$ and the required sample size was 250 children. Adding $20 \%$ for the possible non-response rate, the final sample size was 300 children. A purposive sample was used. All children aged $\leq 5$ years, with cyanotic or acyanotic CHD, but without complications, co-morbidities or subjected to cardiac surgery, were recruited.

Data collection technique: Sociodemographic data in addition to a full medical and family history were gathered through interviewing the children caregivers. Detailed dietary history using a 24-hour recall method was used. Details of feeding practice e,g breast feeding, age at weaning, type and adequacy of weaning foods were recorded. Hemoglobin level, serum iron and total iron binding capacity of the patients were also assessed. Anthropometric measurements namely weight (kilogram), length/height (centimeter), were measured. They were carried out according to standard WHO procedures. $\mathrm{Z}$ scores for weight for age (WAZ), weight for height (WHZ), and height for age (HAZ) were calculated using the 
Anthropometric calculator module of WHO Anthro software. ${ }^{11}$

According to the WHO global database on child growth and malnutrition, moderate underweight was defined as a cutoff $\mathrm{Z}$ score of <-2 low WAZ, stunting as a cut-off $\mathrm{Z}$ score of $<-2$ low HAZ, and wasting as a cut-off $Z$ score of $<-2$ low WHZ. While a $\mathrm{Z}$ score of <-3 SD used to define severe malnutrition. ${ }^{12}$

Pilot testing: The preliminary data collection sheet was tested on 35 caregivers to assess the clarity and comprehension of the questions, and to estimate the time needed for completion the questionnaire. Estimate the time needed for completion of the questionnaire. Some questions were tailored to be clearer and others were removed to avoid repetition

Data managements: A total of 300 questionnaires were fulfilled. Completed forms were revised for completeness and logical consistency. Pre-coded data were entered into the Statistical Package of Social Science (SPSS) version 21.0 to be statistically analyzed. Data were presented as frequencies and percentages for categorical data, range, mean, and standard deviation for quantitative variables. Chi square test was used for association when appropriate. Comparison between groups was performed using independent sample t-test and Mann Whitney test for quantitative variables.

Ethical consideration: Informed consents were obtained from the children's care-givers, and the study was approved by the research ethical committee at the Public Health and Pediatric departments of Cairo University.

\section{Results:}

The socio-demographic characteristics of the studied group were summarized as follows; the majority had ASD 106 (35.3\%), 241 (80.3\%) had acyanotic condition, while 233 (77.7\%) had no complications (Figure-1). One hundred twenty patients (40\%) were scheduled for surgical intervention, 87 of whom $(72.5 \%)$ were recommended to attain a weight of $8 \mathrm{~kg}$ to be liable for surgery.

Height-for-age levels, is showed skewness to the left with a sharp peak as illustrated in (Figure-2), and the mean levels for different age groups was less than -1, with the lowest level in the age range between (3647 ) months of a mean of $-2.03 \pm 0.59$. Heightfor-age levels in the studied patients showed also skewness to the left with a sharp peak, but to a less degree than the weight levels as demonstrated in (Figure-3), and the mean levels for different age groups as less than-1, 
with a peak at the age range of (0-5) months with a mean of $-1.88 \pm 0.58 .58$.Weight-forheight levels, showing a mild skewness to the left and the mean levels for different ages are in the negative values, with a peak value at the age range of (36-47) months with a mean of $1.44 \pm 0.71$ (Table- 1$)$.

The BMI-for-age levels, showed mild skewness to the left as well as the mean levels for different ages were all less than -1 , with a peak value in the age range of (0-5) months with a mean of $-1.27 \pm 0.68 .68$ (Table-2). The prevalence of underweight children among the studied children was 124 (44\%), whereas stunting was $89(29.7 \%)$ and wasting was 20 $(6.7 \%)$ with a total of malnourished patients of $141(47 \%)$. Malnutrition was associated with financial status, where it was significantly higher (P-value 0.038) among children with family's expenditures surpassing their income.

Concerning timing of breastfeeding, malnutrition was found to be significantly lower in those breastfed on regular intervals rather than those fed on demand (with P-value 0.002). Finally, malnutrition was significantly higher in those who received complementary feeding rather than breastfed or bottle-fed only as addressed in table-3(P-value 0.03 ).

\section{Discussion:}

Distinctive sorts of heart deformity can influence nourishment and development to fluctuating degrees. The severity of malnutrition can range from mild undernourishment to inability to flourish. ${ }^{13}$ Nearly half of the studied under-five years of age CHD patients suffered from malnutrition 47\%. This came in concordance with Ratanachu and Pongdara, 2011 in Thailand, studying children with CHD, who found that the overall prevalence of malnutrition was $40 \%$, coinciding with our results. ${ }^{14}$

Earlier studies demonstrated the importance of CHD-related malnutrition predominantly in developing countries; however, prevalence fluctuated largely from $27 \%$ up to $90.4 \% .{ }^{15}$ Costello et al. 2015 in Australia, reported the rates of stunting, wasting and underweight were, $21 \%, 18 \%$ and $23 \%$ respectively. ${ }^{16}$ In the case-control study conducted in Zagazig, more deteriorated results when compared to our study were highlighted. The prevalence of malnutrition was found to be $61.9 \%$ stunted, $23.8 \%$ wasted, and $14.3 \%$ underweight. ${ }^{15}$

This was in contrast to a case-control observational study in Nigeria by Okoromah et al in 2011, who found that the prevalence of stunting, wasting and underweight were 
$28.8 \%, 41.1 \%$, and $20.5 \%$ consecutively. ${ }^{3}$ This was in concurrence with the Egyptian and Demographic Survey (EDHS) 2005 and 2008 respectively, where stunting rather than wasting was found to be the commonest type of malnutrition among the general pediatric population in Egypt. ${ }^{17,18}$

However, the apparently better results detected by our study might be explained by the difference in the clinical status of their included patients, who were predominantly complicated by moderate to severe congestive heart failure, in the previous mentioned studies. However, our results highlighted that the prevalence of acyanotic condition and uncomplicated CHD cases was $(80.3 \%)$ and $(77.7 \%)$ respectively. ${ }^{3,15}$

Another crucial point that could contribute to this disparity is that in Okoromah et al, 2011 and Hassan et al, 2015 studies, they used z score of $\leq-2$ SD as cut off limits to classify malnutrition Whereas in the current study, values of only <-2SD were considered malnutrition, following the WHO child growth standards. ${ }^{12}$ Left skewness of the growth curves, compared to the WHO child growth standard, highlighted that the mean weight-for-age $\mathrm{z}$-score was $-1.9 \pm 0.6$, the mean height-for-age $\mathrm{z}$-score was $-1.8 \pm 0.6$ and the mean weight-for-height z-score was- $1.2 \pm 0.7$. Results from the present study indicated that weight was more affected than height in this population which is supported by Costello et al, 2015. ${ }^{16}$ In the current study, we found a statistically significant difference regarding malnutrition between anemic 95 (32\%) and non-anemic $205(68 \%)$ with $\mathrm{p}$ value $=0.003)$. This came in agreement with Hassan et al, 2015 who also found a significant correlation between anemia and malnutrition. ${ }^{15}$

Further elaboration on the different factors related to malnutrition and financial status was studied in relation to malnutrition, where there was a statistically significant difference between those with an income equalizing or surpassing their expenditure versus those with an income lesser than their expenditure groups concerning their nutritional status with a $\mathrm{p}$ value $=0.038$. This might give a clue that the nutritional status might be associated with food availability and proper feeding practices.

This agrees with Vaidyanathan et al, 2008 and Okoromah et al, 2011 who also found a significant correlation between socioeconomic status and malnutrition in their group of patients. ${ }^{19,3}$ Also, a statistically significant difference $(\mathrm{p}$ value $=0.03)$ was present between those children receiving 
complementary feeding versus those who didn't receive it. Malnutrition was more perceived among children receiving complementary feeding, which could be explained by the improper weaning practice by the mothers. Breastfed children on demand documented a higher prevalence of malnutrition compared to those receiving breast feeding on regular intervals, and the difference was statistically significant (Pvalue $=0.002)$

This emphasizes the poor feeding habits of infants and children in this group of patients, who have poor appetites and take longer to feed. ${ }^{20}$ Therefore, it is important to feed them regularly and not just wait for their demand. The current study didn't show any association with the socio-demographic characters of the CHD children. Where $(93.3 \%)$ of mothers were non-working and there was no statistically significant difference between malnutrition of children who had working or non-working mothers.

This coincides with the results of an Indian study done in 2008 by Vaidyanathan et al. in a tertiary referral hospital to identify determinants of malnutrition in 476 children with congenital heart disease (CHD) and examine the short-term effects of corrective intervention. ${ }^{19}$ Also, the current study didn't detect any statistically significant difference regarding malnutrition between group of patients with illiterate parents and those who received some sort of education. This might be explained by the lack of nutritional knowledge provided in the educational system in Egypt. This comes in agreement with Varan et al, 1999. (13.) However, Vaidyanathan et al. 2008 found a significant difference between educated and illiterate fathers in his Indian study. ${ }^{19}$

On comparing both groups of birth weight (those $\geq 2.5 \mathrm{kgs}$ and those $<2.5 \mathrm{kgs}$ ) considering the nutritional status, there was no statistically significant difference between the two groups, this also agrees with Varan et al, 1999 and Okoromah et al,2011. 13,19 However, Vaidyanathan et al. 2008 found a statistically significant difference between those with low birth weight as a predictor of low weight and height z-scores <-2. ${ }^{19}$

Previous reports on the patterns of malnutrition in acyanotic and cyanotic CHD vary widely. After comparing the nutritional status between cyanotic and acyanotic patients, no statistically significant difference was found. This came in agreement with Vaidyanathan et al, 2008 and this also agrees with Castello et al, 2015 who also didn’t find any significant difference between the two 
groups. ${ }^{19,16}$ This could also be explained by the absence of complications in our study group.

\section{Study Limitation:}

The cross sectional study design restricts evaluation of the relation between different malnutrition predictors among CHD children.

\section{Conclusion:}

Malnutrition is an obvious complicating problem in children with $\mathrm{CHD}$, associated with the existence of anemia, breastfeeding on demand and starting complementary feeding.

A Case Control or prospective cohort study design are recommended to derive more evidence on malnutrition predictors among CHD children.

Nutrition assessment should be mandated as a required and essential component of the cardiology clinic visit for recognition of malnourished children and early referral to dietetic services at any time on diagnosis of acute or chronic malnutrition. Specialized, well trained and updated personnel should continuously perform nutrition counseling with caregivers to help design a healthy and sufficient diet to supply the child with the appropriate nutrition.

Acknowledgments: We would like to thank all patients and care givers who contributed to the completion of this work. Also, we extend our thanks and appreciation to staff members, nurses and at the Pediatric outpatient clinic, who actively contributed to this work.

Funding: The authors affirmed that they didn't receive any grant or fund whether financial or in-kind from any entity

Conflict of Interest Statement: The authors declare that there is no potential conflicts of interest exist with respect to the research, authorship, and/or publication of this article.

\section{References:}

1. Benjamin J. Toole, Lindsay E. Toole, Ursula G. Kyle, Antonio G. Cabrera, Renán A. Orellana, and Jorge A. Coss-Bu, Peri-operative Nutritional Support and Malnutrition in Infants and Children with Congenital Heart Disease, Congenit Heart Dis. 2014;9:15-25.

2. Mehta NM, Costello JM and Bechard LJ. Resting energy expenditure after Fontan surgery in children with single-ventricle heart defects. JPEN J Parenter Enteral Nutr.2012;36(6): 685-692

3. Okoromah CA, Ekure EN, Lesi FE, Okunowo WO, Tijani BO and Okeiyi JC. Prevalence, Profile and predictors of malnutrition in children with congenital heart defects: A case-control observational study.Arch Dis Child. 2011;96(4):354-60. 
4. Nydegger $A$ and Bines JE. Energy metabolism in infants with congenital heart disease. Nutrition (Burbank, Los Angeles County, Calif. 2006;22(7-8): $697-$ 704.

5. Hassan BA, Albanna EA, Morsy SM, Siam AG, Al Shafie MM, Elsaadany HF, Sherbiny HS, Shehab M and Grollmuss

Nutritional Status in Children with Un-

Operated Congenital Heart Disease: An Egyptian Center Experience.Front Pediatr.2015;15;3:53.

6. Vaidyanathan B, Radhakrishnan R, Sarala DA, Sundaram KR, Kumar RK . What determines nutritional recovery in malnourished children after correction of congenital heart defects? Pediatrics. 2009;124(2):e294-9.

7. Hubschman LE. Malnutrition in congenital heart disease: management to improve outcomes. ICAN.2013;5(3):1941406413485906.

8. Medoff-Cooper B and Ravishankar C. Nutrition and growth in congenital heart disease: a challenge in children. CurrOpinCardiol.2013; 28(2):122-9.

9. Weinberg S, Kern J, Weiss K and Ross G. Developmental screening of children diagnosed with congenital heart defects. Clinical Pediatrics.2001; 20, 497-501.

10. Sample size calculator available at http://www.openepi.com/SampleSize/SSP ropor.htm last accessed on May 2016.

11. WHO Anthro (version 3.2.2, January 2011) and macros available at: https://www.who.int/childgrowth/software /en/last accessed on December 2015.

12. WHO Multicentre Growth Reference Study Group. WHO child growth standards based on length/height, weight and age. Acta Paediatr Suppl. 2006; 450:76-85.

doi:10.1080/08035320500495548).

13. Varan B,Tokel $\mathrm{K}$ and Yilmaz $\mathrm{G}$. Malnutrition and growth failure in cyanotic and acyanotic congenital heart disease with and without pulmonary hypertension. ArchDisChild.1999; 81:4952. doi:10.1136/adc.81.1.49.

14. Ratanachu-Ek S and Pongdara A. Nutritional status of pediatric patients with congenital heart disease: pre- and post cardiac surgery. J Med Assoc Thai.2011;94 Suppl 3:S133-7.

15. Hassan BA, Albanna EA, Morsy SM, Siam AG, Al Shafie MM, Elsaadany HF, et al. Nutritional Status in Children with Un-Operated Congenital Heart 
Disease: An Egyptian Center Experience. Front Pediatr. 2015 Jun 15;3:53. doi: 10.3389/fped.2015.00053

16. Costello CL, Gellatly M, Daniel J, Justo RN and Weir K. Growth Restriction in Infants and Young Children with Congenital Heart Disease. Congenit Heart Dis.2015 ;10(5):447-56. doi: 10.1111/chd.12231.

17. El-Zanaty, Fatma and Ann Way. Egypt Demographic and Health Survey 2005. Cairo, Egypt: Ministry of Health and Population, National Population Council, El-Zanaty and Associates, and ORC Macro available

at https://www.dhsprogram.com/pubs/pdf/F R176/FR176.pdf. last accessed December 2014.
18. El-Zanaty, Fatma and Ann Way. Egypt Demographic and Health Survey 2008. Cairo, Egypt: Ministry of Health, ElZanaty and Associates, and Macro International., available at https://dhsprogram.com/pubs/pdf/fr220/fr 220.pdf last accessed on December 2014

19. Vaidyanathan B, Nair SB, Sundaram KR, Babu UK, Shivaprakasha K, Rao SG, et al,. Malnutrition in children with congenital heart disease (CHD) determinants and short term impact of corrective intervention. Indian Pediatr.2008; ;5(7):541-6.

20. Woodward CS. Keeping Children With Congenital Heart Disease Healthy.Journal of Pediatric Health Care. 2011;25(6):3738. 
Table (1): Showing the weight-for-height \% distribution of the studied patients

\begin{tabular}{|c|c|c|c|c|c|c|}
\hline Age groups & No. & Weight-for-lengt & neight $\%$ & & & \\
\hline & & $\% \geq-2 S D-\leq 2 S D$ & $\%<-3$ SD & $\%<-2$ SD & Mean & SD* \\
\hline - Total (0-60) & 300 & 90.6 & 0.7 & 8.7 & -1.16 & 0.67 \\
\hline - (0-5) & 72 & 98.6 & 0 & 1.4 & -0.64 & 0.74 \\
\hline - (6-11) & 66 & 93.9 & 0 & 6.1 & -1.17 & 0.54 \\
\hline - (12-23) & 67 & 89.6 & 0 & 10.4 & -1.38 & 0.55 \\
\hline - (24-35) & 38 & 86.8 & 0 & 13.2 & -1.34 & 0.56 \\
\hline - $(36-47)$ & 26 & 73.1 & 7.7 & 19.2 & -1.44 & 0.71 \\
\hline - (48-60) & 31 & 87.1 & 0 & 12.9 & -1.39 & 0.45 \\
\hline
\end{tabular}


Table (2): Showing the distribution of the BMI-for-age \% of the studied patients

\begin{tabular}{|c|c|c|c|c|c|}
\hline Age groups & No. & BMI*-for-age & & & \\
\hline & & $\% \geq-2 S D-\leq 2 S D$ & $\%<-2 S D$ & Mean & SD \\
\hline - Total (0-60) & 300 & 92 & 8 & -1.19 & 0.57 \\
\hline - (0-5) & 72 & 84.7 & 15.3 & -1.27 & 0.68 \\
\hline - (6-11) & 66 & 92.4 & 7.6 & -1.15 & 0.54 \\
\hline - (12-23) & 67 & 95.5 & 4.5 & -1.11 & 0.52 \\
\hline - (24-35) & 38 & 97.4 & 2.6 & -1.16 & 0.55 \\
\hline - (36-47) & 26 & 88.5 & 11.5 & -1.26 & 0.67 \\
\hline - (48-60) & 31 & 96.8 & 3.2 & -1.28 & 0.43 \\
\hline
\end{tabular}


Table (3): Showing the association between malnutrition and different factors that might affect the nutritional status of the studied patients

\begin{tabular}{|c|c|c|c|c|c|}
\hline & \multicolumn{4}{|c|}{ Malnutrition } & \multirow[b]{3}{*}{$P$ value } \\
\hline & \multicolumn{2}{|c|}{ Yes } & \multicolumn{2}{|c|}{ No } & \\
\hline & $\mathbf{N}$ & $\%$ & $\mathbf{N}$ & $\%$ & \\
\hline $\begin{array}{l}\text { Type of Congenital heart disease } \\
\text { - Cyanotic } \\
\text { - Acyanotic } \\
\end{array}$ & $\begin{array}{c}108 \\
33 \\
\end{array}$ & $\begin{array}{l}76.6 \\
23.4\end{array}$ & $\begin{array}{c}133 \\
26 \\
\end{array}$ & $\begin{array}{l}83.6 \\
16.4\end{array}$ & 0.146 \\
\hline $\begin{array}{l}\text { Financial Status } \\
\text { - } \quad \text { Income<expenditure } \\
\text { - } \quad \text { Income } \geq \text { expenditure }\end{array}$ & $\begin{array}{l}56 \\
85\end{array}$ & $\begin{array}{l}39.7 \\
60.3\end{array}$ & $\begin{array}{c}45 \\
114\end{array}$ & $\begin{array}{l}28.3 \\
71.7\end{array}$ & 0.038 \\
\hline $\begin{array}{l}\text { Mother Work } \\
\text { - } \quad \text { Working } \\
\text { - } \quad \text { Not working } \\
\end{array}$ & $\begin{array}{r}8 \\
133\end{array}$ & $\begin{array}{r}5.7 \\
94.3\end{array}$ & $\begin{array}{r}12 \\
147\end{array}$ & $\begin{array}{r}7.5 \\
92.5\end{array}$ & 0.644 \\
\hline $\begin{array}{l}\text { Mother Education } \\
\text { - } \quad \text { Not educated } \\
\text { - } \quad \text { Educated }\end{array}$ & $\begin{array}{l}56 \\
85\end{array}$ & $\begin{array}{l}39.7 \\
60.3\end{array}$ & $\begin{array}{l}68 \\
91\end{array}$ & $\begin{array}{l}42.8 \\
57.2\end{array}$ & 0.639 \\
\hline $\begin{array}{l}\text { Father Education } \\
\text { - } \quad \text { Not educated } \\
\text { - } \quad \text { Educated }\end{array}$ & $\begin{array}{l}69 \\
72\end{array}$ & $\begin{array}{l}48.9 \\
51.1\end{array}$ & $\begin{array}{l}79 \\
80\end{array}$ & $\begin{array}{l}49.7 \\
50.3\end{array}$ & 0.908 \\
\hline $\begin{array}{l}\text { Illness in the past two weeks } \\
\text { - Yes } \\
\text { - No }\end{array}$ & $\begin{array}{l}74 \\
67 \\
\end{array}$ & $\begin{array}{l}52.5 \\
47.5 \\
\end{array}$ & $\begin{array}{c}100 \\
59 \\
\end{array}$ & $\begin{array}{l}62.9 \\
37.1 \\
\end{array}$ & 0.079 \\
\hline $\begin{array}{l}\text { Timing of breastfeeding } \\
\text { - On demand } \\
\text { - } \quad \text { Regular }\end{array}$ & $\begin{array}{c}105 \\
18\end{array}$ & $\begin{array}{l}81.4 \\
14.0\end{array}$ & $\begin{array}{c}137 \\
5\end{array}$ & $\begin{array}{c}93.2 \\
3.4\end{array}$ & 0.002 \\
\hline $\begin{array}{l}\text { Age of food introduction } \\
\text { - } \quad 4 \text { months } \\
\text { - } \quad 4-6 \text { months } \\
\text { - } \quad>6 \text { months }\end{array}$ & $\begin{array}{l}24 \\
55 \\
26\end{array}$ & $\begin{array}{l}22.9 \\
52.4 \\
24.8\end{array}$ & $\begin{array}{l}26 \\
88 \\
21\end{array}$ & $\begin{array}{l}19.3 \\
65.2 \\
15.6\end{array}$ & 0.103 \\
\hline $\begin{array}{l}\text { Complementary feeding started } \\
\text { - Yes } \\
\text { - } \quad \text { No }\end{array}$ & $\begin{array}{c}105 \\
36\end{array}$ & $\begin{array}{l}74.5 \\
25.5\end{array}$ & $\begin{array}{c}135 \\
24\end{array}$ & $\begin{array}{l}84.9 \\
15.1\end{array}$ & 0.030 \\
\hline $\begin{array}{l}\text { Iron Supplementation } \\
\text { - Yes } \\
\text { - } \quad \text { No } \\
\end{array}$ & $\begin{array}{c}36 \\
105\end{array}$ & $\begin{array}{l}25.5 \\
74.4\end{array}$ & $\begin{array}{c}53 \\
106\end{array}$ & $\begin{array}{l}33.3 \\
66.7\end{array}$ & 0.164 \\
\hline $\begin{array}{l}\text { Vitamin A Supplementation } \\
\text { - Yes } \\
\text { - No }\end{array}$ & $\begin{array}{l}94 \\
47\end{array}$ & $\begin{array}{l}66.7 \\
33.4\end{array}$ & $\begin{array}{c}110 \\
49\end{array}$ & $\begin{array}{l}69.2 \\
30.9\end{array}$ & 0.710 \\
\hline $\begin{array}{l}\text { Weight at Birth } \\
\text { - } \quad<2.5 \mathrm{Kg} \\
\text { - } \quad \geq 2.5 \mathrm{Kg} \\
\end{array}$ & $\begin{array}{l}36 \\
98 \\
\end{array}$ & $\begin{array}{l}26.9 \\
73.1\end{array}$ & $\begin{array}{c}36 \\
114\end{array}$ & $\begin{array}{l}24.0 \\
76.0\end{array}$ & 0.588 \\
\hline $\begin{array}{l}\text { Mother Education } \\
\text { - } \quad \text { Not educated } \\
\text { - } \quad \text { Educated } \\
\end{array}$ & $\begin{array}{l}56 \\
85 \\
\end{array}$ & $\begin{array}{l}39.7 \\
60.3\end{array}$ & $\begin{array}{l}68 \\
91 \\
\end{array}$ & $\begin{array}{l}42.8 \\
57.2\end{array}$ & 0.639 \\
\hline \begin{tabular}{l}
\multicolumn{2}{l}{ Anemia } \\
- $\quad$ Yes \\
- $\quad$ No \\
\end{tabular} & $\begin{array}{l}57 \\
84 \\
\end{array}$ & $\begin{array}{l}40.4 \\
59.6 \\
\end{array}$ & $\begin{array}{c}38 \\
121 \\
\end{array}$ & $\begin{array}{l}23.9 \\
76.1 \\
\end{array}$ & 0.003 \\
\hline
\end{tabular}

*Associations were performed using Chi square test of significance, considering significance P- value $(\leq 0.05)$

Egyptian Family Medicine Journal (EFMJ)

Vol .3(2), Nov. 2019

http://efmj.journals.ekb.eg/ 


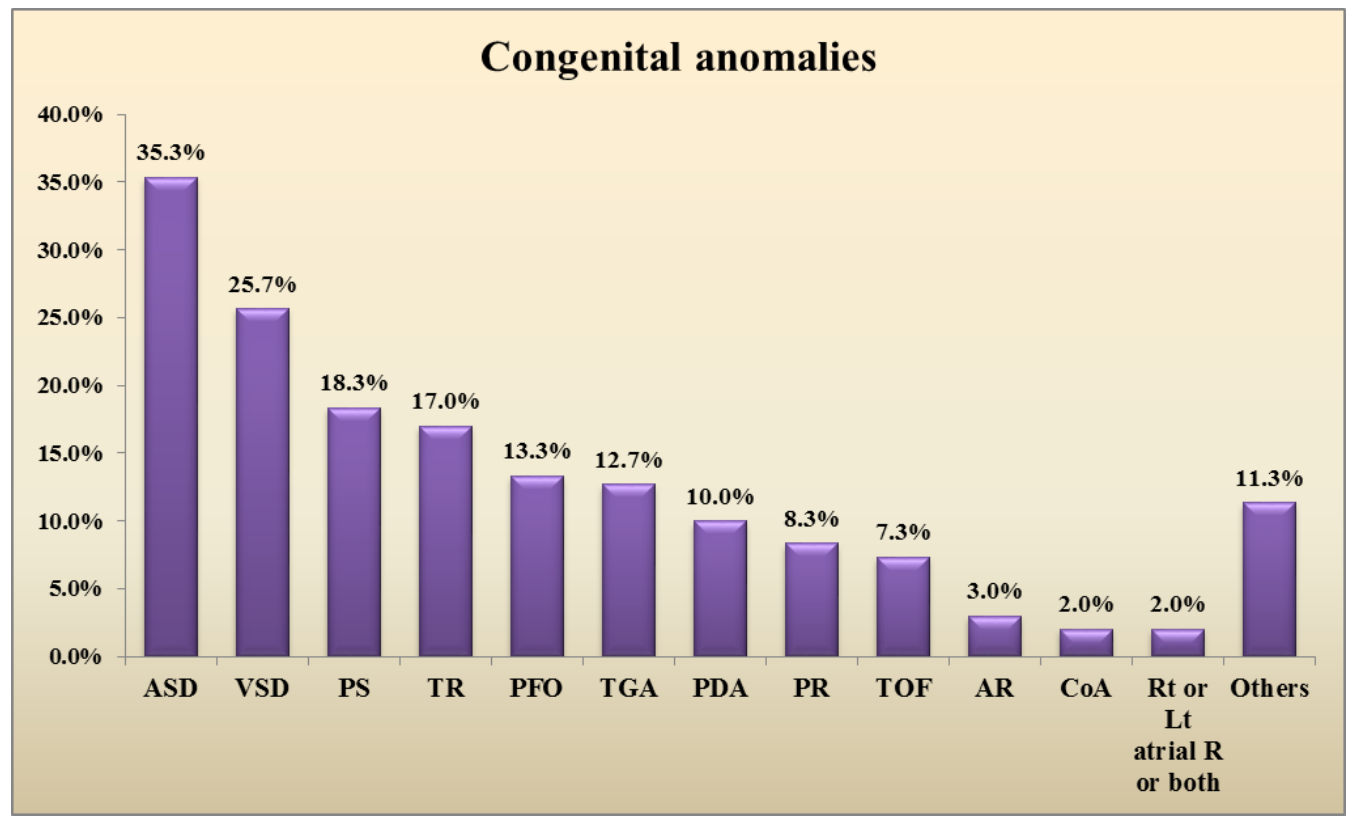

Fig (1): Showing the distribution of different congenital heart disease in the studied patients.

*the total is more that $100 \%$ due to the presence of complex anomalies 


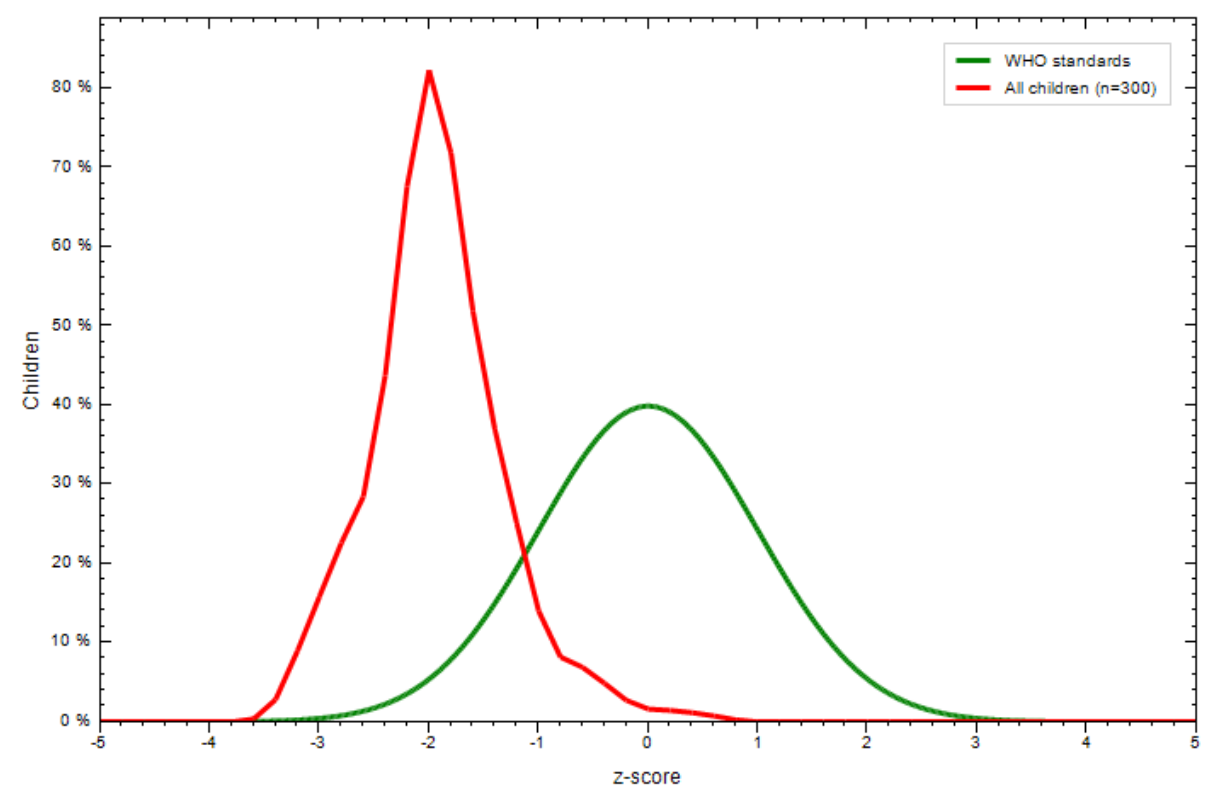

Fig (2): Showing the weight-for-age z-score curve of the studied patients in comparison to the WHO standards.

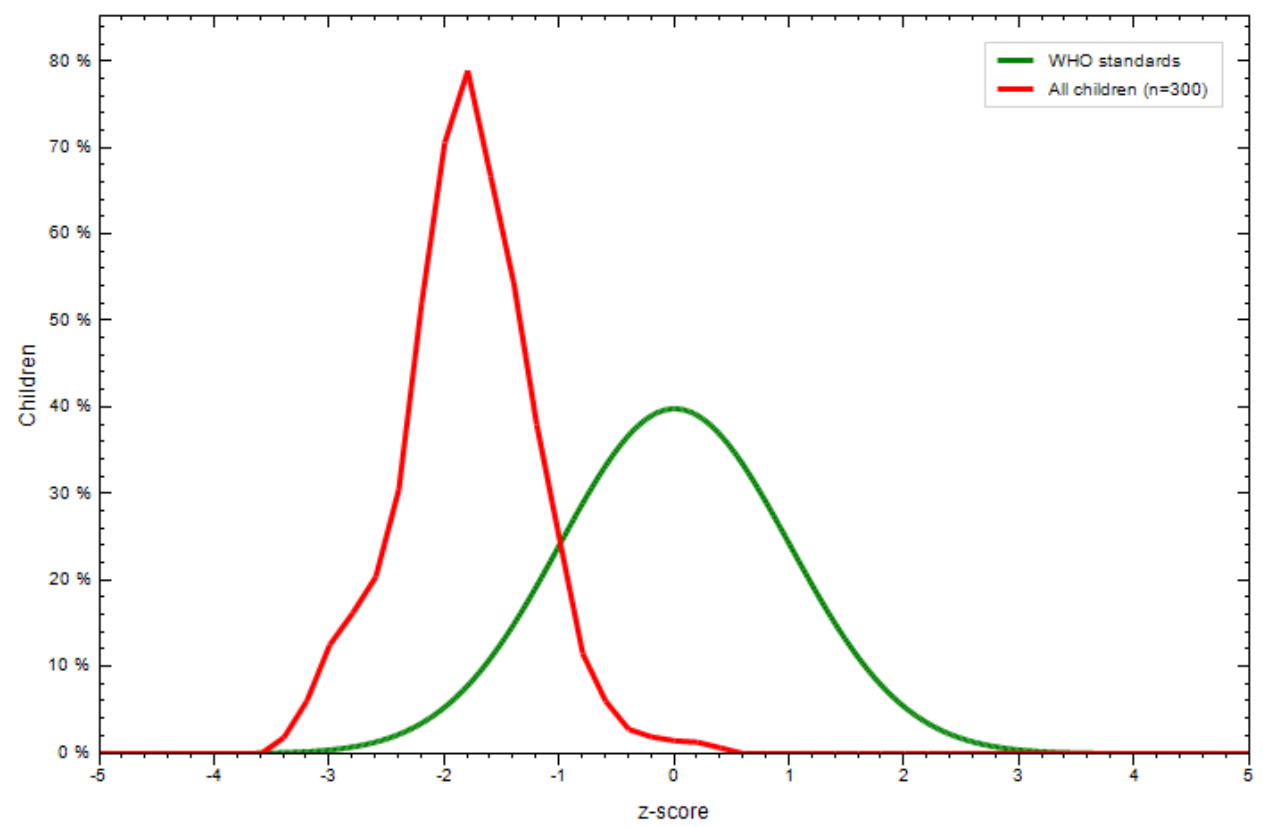

Fig. (3): Showing the length/height-for age $z$-score curve in the studied patients 


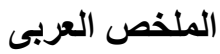

انتشار سوء التفذية لاى الأطفال دون سن الخامسة المصابين بأمراض القلب الخلقية في مستثفيات الأطفال بجامعة القاهرة نرجس البرت لبيب- هالة صلاح حمزة ــ أمل سمير سدر الكـ أميرة أحمد حجازى

الخلفية: يعتبر سوء التغذية بين الأطفال الذين يعانون من أمر اض القلب الخلقية مـن المشكلات الصحية الرئيسية التي تتسبب في تأثثير كبير على معدلات الاعتلال والوفيات بين الأطفال.و قد أثشير إلى ذلك عن طريق الاستشفاء المتكرر ، و النتائج الجر احية الضعيفة ، واستمر ار ضعف النمو الجسدي ، وزيادة معدلات الوفيات. الهـف: هدفت الدر اسة إلى توضيح نمط انتشـار سوء التغذيـة بين الأطفال المصريين دون سن الخامسـة المصـابين أمر اض القلب

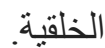

طرق البحث: تضمنت در اسـة تحليلية مقطعيـة 300 طفل ، يعانون مـن أمر اض الثـر ايين التاجيـة غير معقدة. تم تسجيل مستوى

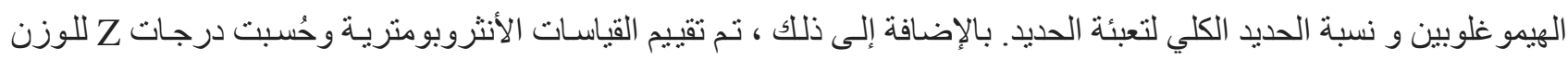
بالنسبة للعمر (WAZ) ، و الوزن للارتفاع (WHZ) ، وتم حساب الارتفاع بالنسبة للعمر (HAZ). تم تعريف سوء التغذية على

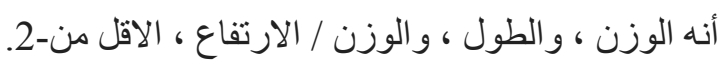
النتائج: كان معدل انتشار سوء التغذية بين عينة الدر اسة للأطفال 47 ٪. وكان أربعة واربعون في المائة من الاطفـال الذين شملتهم الدر اسة يعانون من نقص الوزن ، و 29.7 ٪ يعانون من التقزم ، في حين أن الهزال كان 6.7 ٪ فقط. كان سوء التغذية أقل بكثير في أولئلك الذين يرضعون من الثدي على فترات منتظمة مقارنة مـع اولئك الذين يتم تغذيهم عند الطلب و ايضـا ، كان سوء التغذيـة أعلى بشكل ملحوظ في أولئك الذين يتلقون التغذية التكميلية مقارنة بالرضاعة الطبيعية أو بالزجاجة فقط.

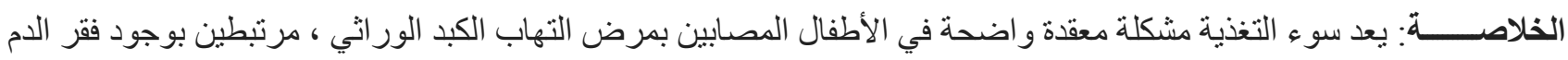
و الرضاعة الطبيعية عند الطلب وبداية التغذية التكميلية. التوصيات: ينصح تصميم در اسة القطيع لاشتقاق المزيد من الأدلة على تنبؤ سوء التغذية بين الأطفال الذين يعنون من عيوب القلب 